\title{
Editorial • • • •
}

Prezadosleitores:

A presente edição da Revista Movimento representa o encerramento de uma etapa significativa de seu projeto editorial, etapa que se caracterizou como um período profícuo no que se refere à sua consolidaçãono contexto dos periódicos brasileiros etambémà sua categorização como periódico de largo espectro editorial, isto é, nojargão acadêmico, uma revista "guardachuva".

Emboracientes de que a Revista representava a polifonia da área de conhecimento, nos últimosmeses, a Comissão Editoriale orientadores do Programade Pós-Graduaçãoem Ciências doMovimento Humano, depois de refletirem em profundidade, entre outros assuntos, decidirampropor estratégias para adequar as revistas editadas pela Escola de Educação Física aos padrões técnicos exigidos para indexaçãonas bases de dadosnacionais e internacionaise, também, articular seus projetos editoriais tendo em vista a consolidação das linhas de pesquisa em desenvolvimento pelos professores da instituiçãona pós-graduação ena graduação.

Nesse sentido, revisando decisões anteriormente tomadas, oconsensopossívelfoide que a Revista Movimento deve abandonar o caráter "guarda-chuva", especializar-se e buscar, doravante, desenvolver seu projeto editorial sob a inspiraçãodas ciências humanas e sociais, já que, do ponto de vista histórico, essa revista constituiu-se publicando em maior número artigos sobre temas, polêmicos ou não, vinculados a questões da natureza pedagógica da Educação Física, ao desenvolvimento profissional da comunidade de especialistas e à reflexão sócio-antropológicadofenômeno esportivo.

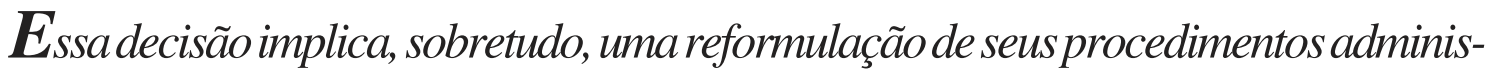
trativos, de seu conselho editorial e do seu projeto gráfico, já que também hánecessidade de revisar os custos de sua publicação.

Enquanto as novidades não ganham visibilidade, oferecemos nessa edição, semperda de qualidade, um material excelente, capaz de despertar o interesse de nossos assíduos leitores. Além de retornar a Seção Mercosul, com um texto de Maria Graciela Rodriguez, colaboramnessa edição Eunice Helena Tamiosso Vega, Gisele Carreirão Gonçalves, Alexandre Fernandez Vaz, Luciano Lazzaris Fernandes, Livia Tenório Brasileiro, Sofia Rubinstein, MariaHelenada Silva Ramalho, Francisco CamargoNetto, MarisaMendes Götze, BennoBecker Jr. Meri Rosane Santos da Silva.

Atodos, boaleitura.

OsEditores 